\title{
Effects of photoperiod on reproduction of Siamese fighting fish Betta splendens
}

\author{
Luiz Gustavo Giannecchini $^{1}$, Haluko Massago ${ }^{1}$, João Batista Kochenborger Fernandes ${ }^{1}$ \\ ${ }^{1}$ Centro de AquaAquaculture Center of UNESP - CAUNESP, Jaboticabal, São Paulo, Brazil, 14884-900.
}

ABSTRACT - This study investigated the effect of different photoperiods (24 h of light (L):0 h of darkness (D); 20L:4D; 16L:8D; 12L:12D; and 8L:16D) on the reproduction and growth of Betta splendens. The results showed that spawning frequency was significantly higher in couples reared under 16L:8D and 12L:12D, in comparison with other treatments. The highest number of eggs per spawn was obtained under 16L:8D (544.76 \pm 375.23$)$ and 12L:12D (471.13 \pm 261.52$)$, and the lowest values were detected for 24L:0D (128.55 \pm 58.14$)$ and 20L:4D (187.87 \pm 103.84$)$. Fertility and fecundity also showed significantly higher average values in 16L:8D and 12L:12D when compared with $24 \mathrm{~L}: 0 \mathrm{D}$ and $20 \mathrm{~L}: 4 \mathrm{D}$ treatments. Egg volume and perivitelline space were significantly higher in 24L:0D treatments that showed the lowest numbers of eggs per spawn, while the vitelline volume did not show significant differences. Other variables such as breeders weight gain and condition factor (K) were not statistically different. Moreover, the final length varies according to photoperiod and gender. These results demonstrated a key role for the photoperiod upon B. splendens reproduction. The best reproductive performance is achieved under the photoperiods that best approached those that occur in spring and summer (16L:8D and 12L:12D), coinciding with their best seasons for reproduction.

Key Words: egg production, fertility, light regimen, ornamental fish

\section{Introduction}

Every year, the world market demands larger quantities of ornamental fish. This is clearly demonstrated by high rates of growth of exports from major producing countries, which reached $11.6 \%$ in 2006 (Fishstat, 2011). The aquarium popularization is due to the currently existing technologies that allow the hobbyist to access and maintain a wide variety of species (Watson \& Shireman, 1996).

The photoperiod directly influences the fish behavior, especially in their feeding and reproductive habits (LoweMcConnell, 1999). The photoperiod effect on fish species reproduction is an important factor to be studied.

Species such as Barbus barbus have their reproduction affected by photoperiod and the interruption of the dark period by light exposure for several hours increases the number of egg masses in relation to animals kept in conditions of normal uninterrupted photoperiod (Poncin, 1992).

Worldwide, $B$. splendens stands out as one of the most beautiful, best-selling and popular ornamental fish from tropical waters (Chapman et al. 1997; Lima, 2003). B. splendens is originated from in Southeast Asia (Thailand, Malaysia) and is also known in English as Siamese fighting fish because of its aggressive behavior against fishes of the same species.
To enable and enhance the captivity production of these fish, it is essential to have knowledge of reproduction. The reproductive performance is most often the deciding factor on the economic viability of fish production. Management techniques should be studied to improve reproductive performance and spawning frequency, number of eggs and hatching rate. However, with ornamental species, there are few studies directed to the development and optimization of these techniques, such as alternatives in induced spawning (Hill et al. 2005).

The objective of this study was to evaluate the photoperiod effects on the reproductive performance of $B$. splendens in order to improve the reproductive management of the species in captivity.

\section{Material and Methods}

The experiment was conducted at the Research Laboratory of Ornamental Fishes of Aquaculture Center at UNESP, Jaboticabal, São Paulo, during 150 days.

In this study, 30 sexually mature pairs of B. splendens super delta strain, with males presenting $3.84 \pm 0.13 \mathrm{~cm}$ (standard length) and $1.92 \pm 0.28 \mathrm{~g}$ and females $3.72 \pm 0.18 \mathrm{~cm}$ and $1.72 \pm 0.23$ g reared individually in 2-liter aquaria until the mating were used. The design was completely randomized 
$(5 \times 2)$ with five light treatments (8 h of light (L):16 h of darkness (D), 12L:12D, 16L:8D; 20L:4D and 24L:0D) and two genders (male and female) with six replicates.

After the males constructed the nests, the fish were kept together for spawning and egg collection. Then breeders were separated and sent back to their original aquarium. They were kept in a water bath at the same temperature provided by four 200-watt heaters to maintain temperature $\left(28^{\circ} \mathrm{C}\right)$ and a submerged pump BOYU model $2000 \mathrm{~L} / \mathrm{h}$ for the movement of water between the boxes.

Each box that housed the aquarium was covered with polyethylene caps trimmed with fluorescent lamps of $60 \mathrm{~cm}$ "Daylight" with 20 watts, providing 500-lux (Lutron Light Meter, model LX-105) lighting within each experimental tank with its lid and automatically turned on and off by analogical timers. The total exchange of water and cleaning of the aquarium were performed every two days, and feeding was done twice daily with commercial diet with $45 \%$ crude protein (CP) and $12 \%$ fat (0.8 mm AQUAXCEL 4512 Purina $\left.{ }^{\circledR}\right)$ until apparent satiation. All the handling was performed during the light photoperiod treatments.

The water supply in the experimental aquariums had the following physicochemical characteristics: $\mathrm{pH} 6.9 \pm 0.3$, dissolved oxygen $>5.0 \mathrm{mg} \mathrm{L}^{-1}$ and ammonia $<0.1 \mathrm{mg}$. $\mathrm{L}^{-1}$. Monitoring of the $\mathrm{pH}$ (pH meter YSI, model PH100) and dissolved oxygen (oximeter YSI model 55) was performed weekly. The concentration of ammonia (CELM spectrophotometer, Model E-225D) was held at the beginning of the experiment and after the reproductive period, in which the tank remained four days without water renewal. The temperature was monitored daily by maximum and minimum thermometer. These physical and chemical characteristics of water were adequate for the maintenance and breeding freshwater ornamental fishes in all photoperiods (Yanong, 1996).

During the mating, the presence of eggs in the nests of bubbles was observed; all the eggs were collected with a plastic Pasteur pipette, separated from the nest of bubbles using a sieve of 120 microns and then fixed in buffered formaldehyde solution $10 \%$ for 24 hours. After this stage, they were washed in $70 \%$ alcohol and kept in this solution for further analysis.

The fertile and dead eggs of each spawning were counted through an optical microscope. The dead eggs were identified through the integrity of the yolk and coloring. The major diameter (D) and minor diameter (d) of the eggs and of the yolk were measured with the aid of an optical microscope equipped with a micrometric lens, for calculating the volume of eggs/yolk and perivitelline space.
To evaluate growth, the fish were measured and weighed at the beginning and at the end of the experiment. The fishes weight gain (WG) and length gain (LG) were calculated as the difference between the results of weight and length of the beginning and the end of the experimental period.

The reproductive performance was evaluated with the following parameters: total fertility rate (ratio of the number of eggs and the number of egg masses), relative fecundity (ratio of average number of eggs per gram of initial weight of the female), spawning frequency; number of eggs, fertility, egg production (ratio between the total number of eggs and the frequency of egg), egg volume and volume of the yolk (given by $\mathrm{V}=(\pi / 6)$. D. $\mathrm{d}^{2}$, where $\mathrm{D}$ is the major diameter in horizontal axis and $d$ is the minor diameter in vertical axis of egg) and perivitelline space (difference between egg volume and yolk volume).

The analysis was performed using the statistical program SAS (Statistical Analysis System, version 9.0). Data were checked by the Levene homogeneity test, Cramer-von Mises normality test and submitted to ANOVA. Differences $(\mathrm{P}<0.05)$ between means were compared by Tukey test. The percentage rates of survival and frequency of spawns were transformed in arcsine $\left(\mathrm{x}^{1 / 2}\right)$ before analysis.

\section{Results and Discussion}

There were no significant interaction between the independent variables (photoperiod and gender) $(\mathrm{P}>0.05)$. The final weight and weight gain were not significantly different between photoperiods ( $\mathrm{P}>0.05$ ) (Table 1 ).

The females gained weight significantly more than males $(\mathrm{P}<0.05)$. This fact is explained by the gonadal development of females during the successive periods of reproduction (Lubzens et al., 2010; Taranger et al., 2010).

The final length did not differ between treatments, only between sexes. Since they were adult animals, the increase in length was higher only in females because they are the smallest, but they can achieve the same length as males over time (Monvises et al., 2009).

While the production-related parameters showed few differences, the parameters related to reproduction show significant differences in relation to photoperiod.

The frequency of spawning (Figure1-A) was higher $(\mathrm{P}<0.05)$ in fish subjected to photoperiods of 16, 12 (long days), and with 8 hours of light (short day), while the longer photoperiods, 20L:4D and 24L:0D, had the lower spawning frequency.

Very long and/or very short photoperiods interfere on sexual development and reproductive periodicity of many 
Table 1 - P values, coefficient of variation (CV), averages of final weight (FW), final length (FL), weight gain (WG) and gain in length (LG) for B. splendens

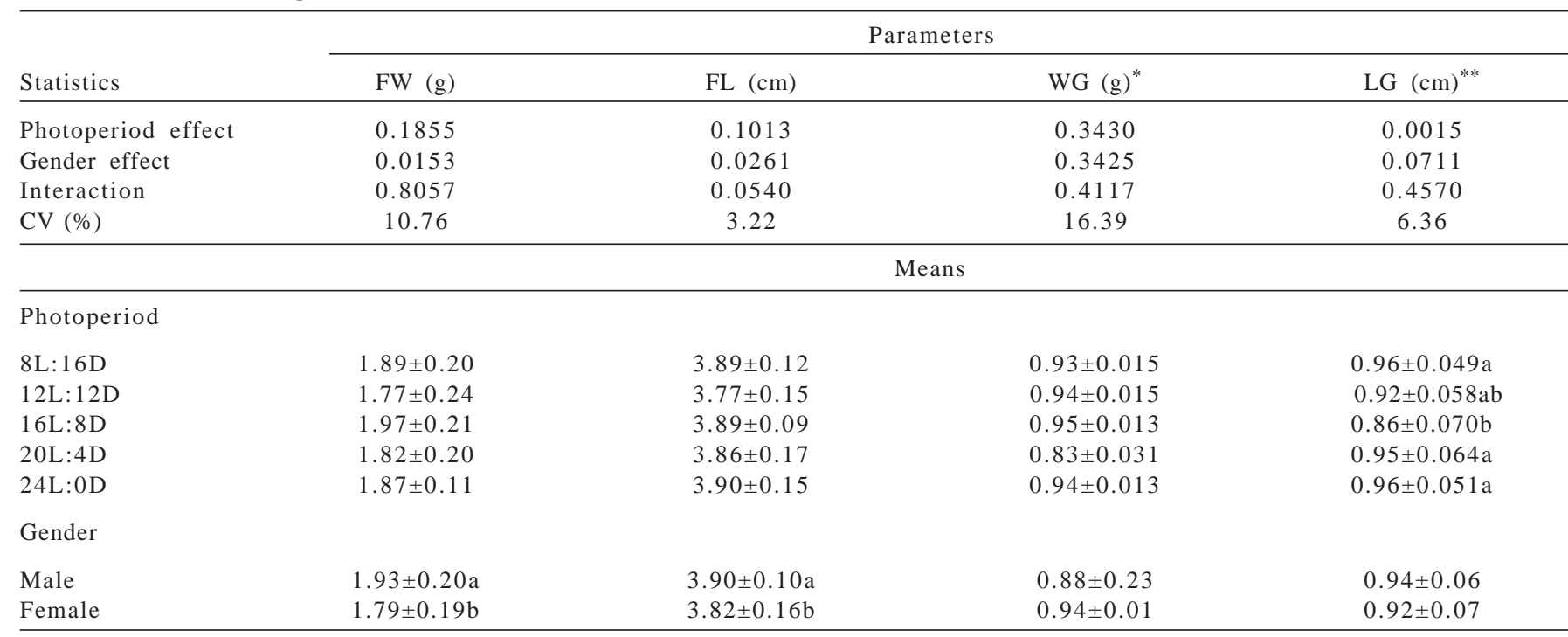

Means within column without letters do not differ $(\mathrm{P}<0.05)$ by Tukey test.

${ }^{*}$ Transformed variable $\mathrm{WG}^{0.01819}$.

${ }^{* *}$ Transformed variable $(\mathrm{LG}+1)^{-1.089225}$.

species. Duston \& Bromage (1986), studying females of rainbow trout Oncorhynchus mykiss, noted an advance in the reproductive period of 2 months with constant and long photoperiods and a delay of up to 4 months with short photoperiod in comparison with the control group (natural photoperiod).

An advance of 2 months in the reproductive period was also observed by Howell et al. (2003) in Centropistis striata subjected to 15 hours of light per day for 12 months. Duston et al. (2003), testing the effects of decreasing photoperiod (16L:8D, reducing to 8L:16D) on sexual maturation of Salvelinus alpinus, found reduction of up to $66 \%$ on sexual maturation of males and $32 \%$ in females, thus delaying the reproductive cycle.

Kissil et al. (2001) observed a delay of up to 3 months in the reproductive period of Sparus aurata when subjected to a photoperiod of 15 hours and half in relation to natural photoperiod. These results show how the photoperiod affects the reproduction of several fish species, interfering with the control of gonadal maturation and preparation for reproduction, so that out of their photoperiod genetically programmed by the species throughout its evolution, there is a delay or even inhibition of reproduction (Amano et al., 2000, 2003; Bromage et al., 2001; Maitra \& Chattoraj, 2007).

As the photoperiod affects the frequency of spawning, the total fertility rate (Figure 1-B), relative fecundity (Figure 1-C) and egg production (Figure 1-D) were also influenced and followed the same trend of the previous one, with the best results for the photoperiods $16 \mathrm{~L}: 8 \mathrm{D}$ and 12L:12D compared with other photoperiods. Similar results were obtained with tilapia subjected to a photoperiod 18L:6D, with higher egg production compared with other photoperiods due to action of melatonin on the hypothalamic-pituitary-gonadal triggering the release of hormones responsible for gametogenesis and maturation of gametes (Ridham \& Cruz, 2000; Campos-Mendoza et al., 2004; Rad et al., 2006).

The action of photoperiod on release of melatonin promotes increased gametogenesis in fish (Davies et al., 1999; Rad et al., 2006), and consequently an increase in the number of eggs. The vitellogenesis is also affected, albeit in a more discreet by photoperiod, as described by Shimizu (2003).

Fertility was also influenced by the exposure of fish to the photoperiods $16 \mathrm{~L}: 8 \mathrm{E}$ and $12 \mathrm{~L}: 12 \mathrm{D}$, providing the best rates (Figure 1-E).

Temperate fish that spawn in increasing photoperiods, like Perca fluviatilis, have low fertility when subjected to long photoperiods like 16 hours (3.3 $\pm 5.8 \%$ ) or 24 hours of light, because these differ greatly from their natural photoperiods on the breeding season (Migaud et al., 2006). Even in tropical fishes, such as $B$. splendens, which do not have a defined breeding season, fertility was affected by photoperiod, one of the most important abiotic factors that act in the maturation of gametes and quality of spawning (Bromage et al., 2001; Tsadik \& Bart, 2007; Lubzens et al., 2010). 
A

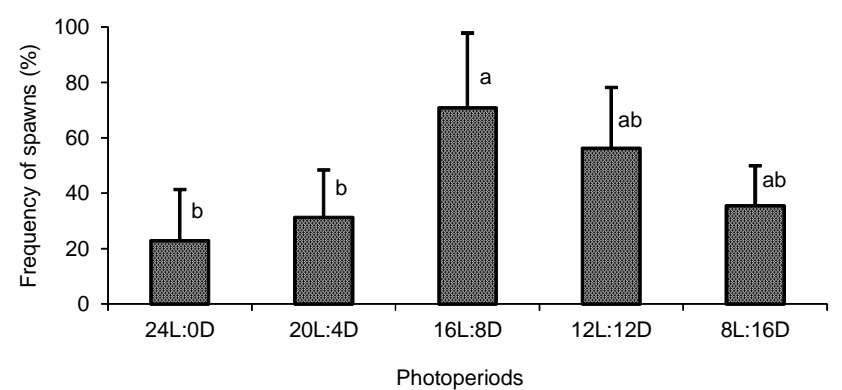

C

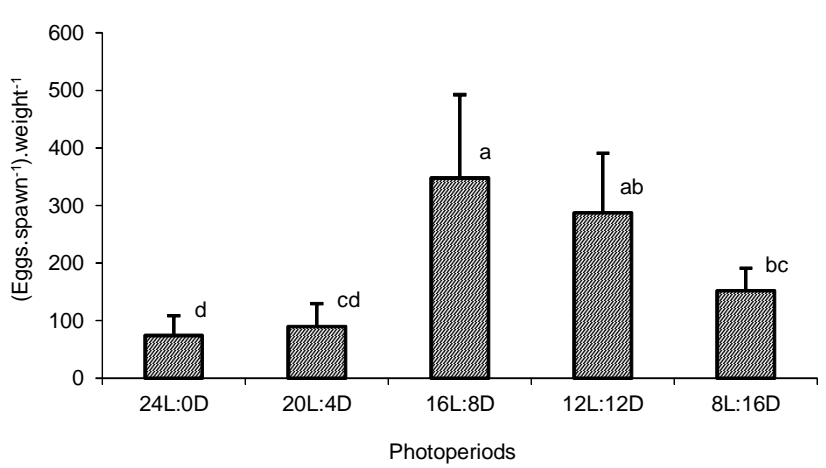

E

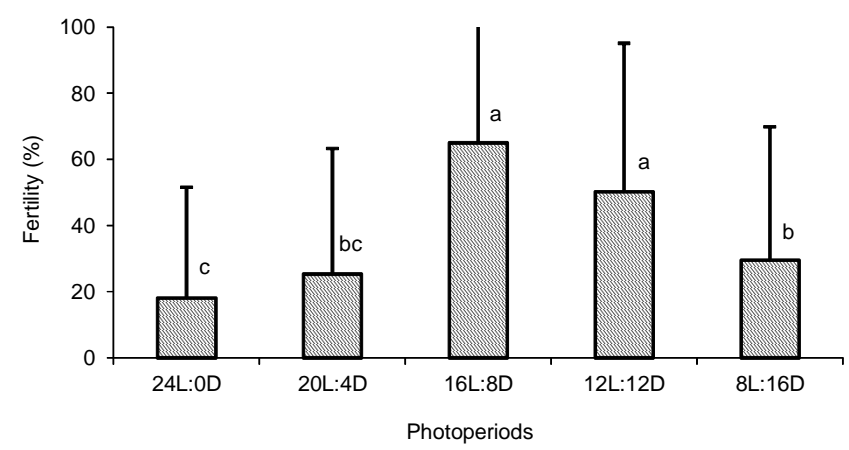

B
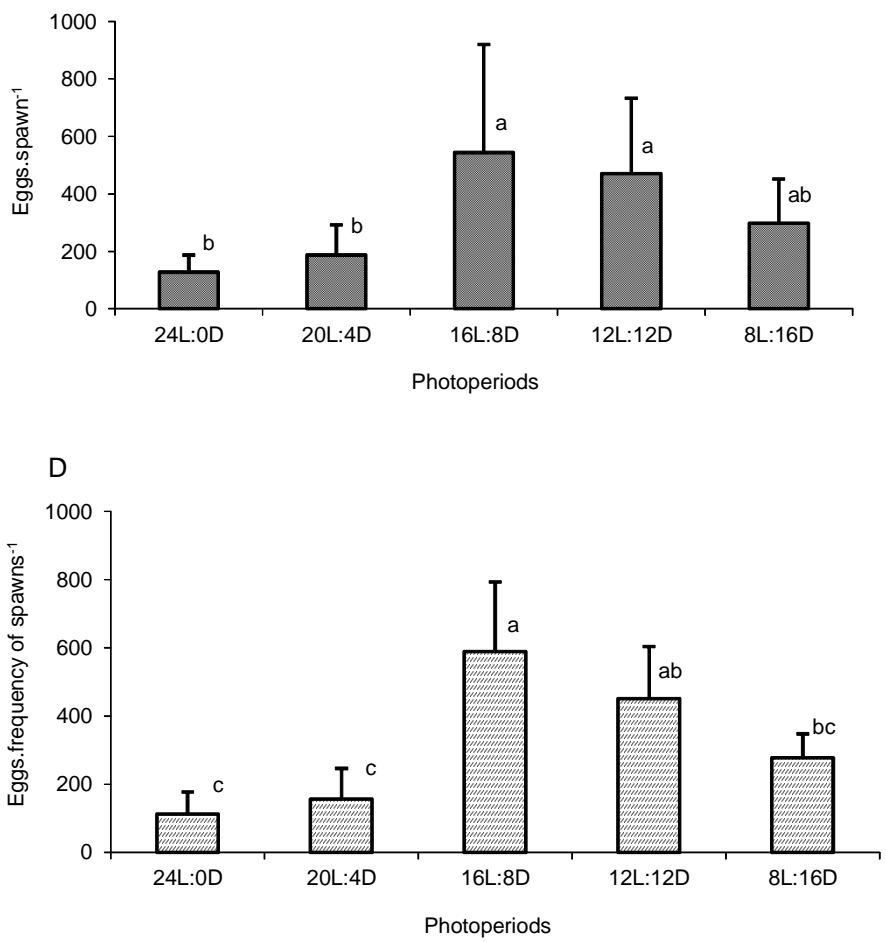

$\mathrm{F}$

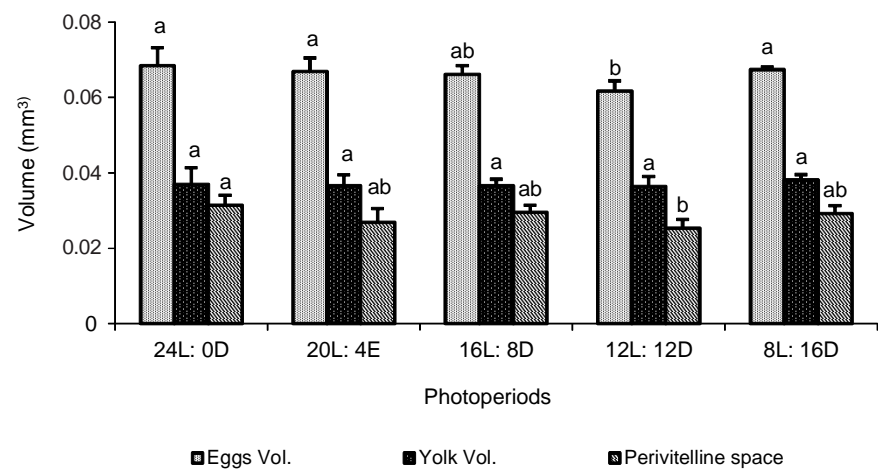

L - light; D - darkness. Columns followed by same letter do not differ significantly $(\mathrm{P}>0.05)$.

Figure 1 - Frequency of spawns $(\mathrm{P}=0.0026)(\mathrm{A})$, total fecundity $(\mathrm{P}<0.0005)(\mathrm{B})$, relative fecundity $(\mathrm{P}<0.0001)(\mathrm{C})$, egg production $(P<0.0001)(D)$, fertility $(P<0.0001)(E)$, egg volume $(P=0.0123)$, yolk volume $(P=0.1918)$ and perivitelline space $(P=0,0118)$ of eggs (F) from $B$. splendens under different photoperiods (mean + standard deviation).

The volumes of the eggs of $B$. splendens showed difference $(\mathrm{P}<0.05)$ in the different photoperiods. The treatments in which females previously had lower fecundity and egg production (24L:00D, 20L:04D and 08L:16D), had greater egg volume than those which presented the largest amount of eggs (Figure 1-F). Female fish usually outweigh a lower production of eggs with larger volume (Duarte \& Alcaraz, 1989) and although the egg size can affect fertility and hence the hatching rate (Coleman \& Galvani, 1998); this was not observed in this study regarding the fertility rate. The egg size can vary depending on the age, physical, physiological of breeders and on the environmental conditions, such as the photoperiod (Brooks et al. 1997; Bonislawska et al., 2000, 2001).

The volume of the yolk by itself, did not show significant difference $(\mathrm{P}>0.05$ ) between treatments (Figure 1-F), as observed by Mañanós et al. (1997), but observing the perivitelline space, which differed between treatments $(\mathrm{P}<0.05)$, it is possible to see that the treatments that showed eggs in larger size, also increased perivitelline space and consequently smaller volumes of yolk in relation to the volume of the egg. Thus, with great spawning, 
although with smaller eggs, there is greater yolk volume, which contributes to higher fertility rate by these treatments, through supporting the initial development of the embryo, as many authors suggest (Linhart et al., 1995; Brooks et al., 1997; Coward \& Bromage, 1999; Bobe \& Labé, 2009).

Mortality during the experimental period did not show significant differences $(\chi 2<0.01)$ between treatments nor was it connected to the photoperiod. Although the most frequent cause of death was due to confrontations between male and female during the mating, as observed by Howell et al. (2003), other studies showed that very long photoperiods, especially the continuous light, showed higher percentages of mortality than long photoperiods (Sigholt et al., 1995; Appelbaum \& Kamler, 2000; Giri et al., 2002; Adewolu et al., 2008).

\section{Conclusions}

The photoperiods that most naturally resemble the occurrence in the summer and spring ( $16 \mathrm{~h}$ of light +08 hours of darkness and $12 \mathrm{~h}$ of light $+12 \mathrm{~h}$ of darkness) promote better reproductive performance of Betta splendens.

\section{References}

ADEWOLU, M.A.; ADENIJI, C.A.; ADEJOBI, A.B. Feed utilization, growth and survival of Clarias gariepinus (Burchell 1822) fingerlings cultured under different photoperiods. Aquaculture, v.238, p.64-67, 2008.

AMANO, M.; IIGO, M.; IKUTA, K. et al. Roles of melatonin in gonadal maturation of underyearling precocious male masu salmon. General and Comparative Endocrinology, v.120, p.190-197, 2000.

AMANO, M.; IIGO, M.; IKUTA, K. et al. Daily variations in melatonin binding sites in the masu salmon brain. Neuroscience Letters, v.350, p.9-12, 2003.

APPELBAUM, S.; KAMLER, E. Survival, growth, metabolism and behaviour of Clarias gariepinus (Burchell 1822) early stages under different light conditions. Aquaculture Engineering, v.22, p.269-287, 2000.

BOBE, J.; LABBÉ, C. Egg and sperm quality in fish. General and Comparative Endocrinology, v.165, p.535-548, 2009.

BONISLAWSKA, M.; FORMICKI, K.; WINNICKI, A. Size of eggs and duration of embryogenesis in fishes. Acta Ichthyologica et Piscatoria, v.30, n.1, p.61-71, 2000.

BONISLAWSKA, M.; FORMICKI, K.; KORZELECKA-ORKISZ, A. et al. Fish egg size variability: biological significance. Electronic Journal of Polish Agricultural Universities, Fisheries, v.4, n.2, p.1-15, 2001.

BROMAGE, N.; PORTER, M.; RANDALL, C. The environmental regulation of maturation in farmed finfish with special reference to the role of photoperiod and melatonin. Aquaculture, v.197, p.63-98, 2001.

BROOKS, S.; TYLER, C.R.; SUMPTER, J.P. Egg quality in fish: what makes a good egg? Reviews in Fish Biology and Fisheries, v.7, p.387-416, 1997.

CAMPOS-MENDOZA, A.; MCANDREW, B.J.; COWARD, K. et al. Reproductive response of Nile tilapia (Oreochromis niloticus) to photoperiodic manipulation; effects on spawning periodicity, fecundity and egg size. Aquaculture, v.231, p.299-314, 2004.
CHAPMAN, F.A.; FITZ-COY, S.; THUNBERG, J.T. United States of America International Trade in Ornamental Fish. Journal of the World Aquaculture Society, v.28, p.1-10, 1997.

COLEMAN, R.M.; GALVÁNI, A.P. Egg size determines offspring size in neotropical cichlid fishes (Teleostei: Cichlidae). Copeia, v.1, p.209-213, 1998.

COWARD, K; BROMAGE, N.R. Spawning periodicity, fecundity and egg size in laboratory-held stocks of a substrate-spawning tilapiine, Tilapia zilli (Gervais). Aquaculture, v.171, p.251-267, 1999.

DAVIES, B.; BROMAGE, N.; SWANSON, P. The Brain-PituitaryGonadal axis of female rainbow trout Oncorhynchus mykiss: Effects of photoperiod manipulation. General and Comparative Endocrinology, v.115, p.155-166, 1999.

DUARTE, C.M.; ALCARAZ, M. To produce many small or few large eggs: a size independent reproductive tactic of fish. Oecologia, v.80, p.401-404, 1989.

DUSTON, J.; BROMAGE, N. Photoperiodic mechanisms and rhythms of reproduction in the female rainbow trout. Fish Physiology and Biochemistry, v.2, p.35-51, 1986.

DUSTON, J.; ASTATKIE, T.; MacISAAC, P.F. Long-to-short photoperiod in winter halves the incidence of sexual maturity among Arctic charr. Aquaculture, v.221, p.567-580, 2003.

FISHSTAT PLUS. Universal software for fishery statistical time series. Version 2.3. Rome: FAO Fisheries Department, Fisheries information, Data and Statistics Unit., 2011.

GIRI, S.S.; SAHOO, S.K.; SAHU, B.B. et al. Larval survival and growth in Wallago attu (Bloch and Schneider): effects of light, photoperiod and feeding regimes. Aquaculture, v.213, p.151-161, 2002.

HILL, J.E.; BALDWIN, J.D.; GRAVES, J.S. et al. Preliminary observations of topical gill application of reproductive hormones for induced spawning of a tropical ornamental fish. North American Journal of Aquaculture, v.67, n.1, p.7-9, 2005. HOWELL, R.A.; BERLINSKY, D.L.; BRADLEY, T.M. The effects of photoperiod manipulation on the reproduction of black sea bass, Centropristis striata. Aquaculture, v.218, p.651-669, 2003.

KISSIL, G.W.; LUPATSCH, I.; ELIZUR, A. et al. Long photoperiod delayed spawning and increased somatic growth in gilthead seabream (Sparus aurata). Aquaculture, v.200, p.363-379, 2001.

LIMA, A.O. Aqüicultura ornamental: o potencial de mercado para algumas espécies ornamentais: Formas alternativas de diversificação da produção na aqüicultura brasileira. Revista Panorama da Aqüicultura, v.13, p.23-29, 2003.

LINHART, O.; KUDO, S.; BILLARD, R. et al. Morphology, composition and fertilization of carp eggs: a review. Aquaculture, v.129, p.75-93, 1995.

LUBZENS, E.; YOUNG, G.; BOBE, J. et al. Oogenesis in teleosts: how fish eggs are formed. General and Comparative Endocrinology, v.165, n.3, p.367-389, 2010.

LOWE-McCONNELL, R.H. Estudos ecológicos de comunidades de peixes tropicais. São Paulo: EDUSP, 1999. 535p.

MAITRA, S.K.; CHATTORAJ, A. Role of photoperiod and melatonin in the regulation of ovarian functions in Indian carp Catla catla: basic information for future application. Fish Physiology and Biochemistry, v.33, p.367-382, 2007.

MAÑANÓS, E.L.; ZANUY, S.; CARRILLO, M. Photoperiodic manipulations of the reproductive cycle of sea bass (Dicentrarchus labrax) and their effects on gonadal development, and plasma $17 ß$-estradiol and vitellogenin levels. Fish Physiology and Biochemistry, v.16, p.211-222, 1997.

MIGAUD, H.; WANG, N.; GARDEUR, J.N. et al. Influence of photoperiod on reproductive performances in Eurasian perch Perca fluviatilis. Aquaculture, v.252, p.385-393, 2006.

MONVISES, A.; NUANGSAENG, B.; SRIWATTANAROTHAI, N. et al. The Siamese fighting fish: Well-known generally but littleknown scientifically. ScienceAsia, v.35, p.8-16, 2009.

PONCIN, P. Influence of the daily distribution of light on reproduction in the barbel, Barbus barbus (L.) Journal of Fish Biology, v.41, p.993-997, 1992. 
RAD, F.; BOZAOĐLU, S.; GÖZÜKARA, S.E. et al. Effects of different long-day photoperiods on somatic growth and gonadal development in Nile tilapia (Oreochromis niloticus L.). Aquaculture, v.255, p.292-300, 2006.

RIDHA, M.T.; CRUZ, E.M. Effect of light intensity and photoperiod on Nile tilapia Oreochromis niloticus L. seed production. Aquaculture Research, v.31, p.609-617, 2000.

SHIMIZU, A. Effect of photoperiod and temperature on gonadal activity and plasma steroid levels in a reared strain of the mummichog (Fundulus heteroclitus) during different phases of its annual reproductive cycle. General and Comparative Endocrinology, v.131, p.310-324, 2003.

SIGHOLT, T.; STAURNES, M.; JAKOBSEN, H.J. et al. Effects of continuous light and short-day photoperiod on smolting, seawater survival and growth in Atlantic salmon (Salmo salar). Aquaculture, v.130, p.373-388, 1995.

TARANGER, G.L.; CARRILLO, M.; SCHULZ, R.W. et al. Control of puberty in farmed fish. General and Comparative Endocrinology, v.165, n.3, p.483-515, 2010.

TSADIK, G.G.; BART, A.N. Effects of feeding, stocking density and water-flow rate on fecundity, spawning frequency and egg quality of Nile tilapia, Oreochromis niloticus (L.). Aquaculture, v.272, p.380-388, 2007.

YANONG, R.P.E. Reproductive management of freshwater ornamental fish. Seminars in Avian and Exotic Pet Medicine, v.5, p.222-235, 1996.

WATSON, C.G.; SHIREMAN, J.V. Production of ornamental aquarium fish - FA35. Gainesville: Institute of Food and Agricultural Sciences - University of Florida, 1996. 4p. 